\title{
A escola primária como tema do debate político às vésperas da República *
}

Carlota Boto

UNESP-Araraquara/UniversidadeMackenzie

RESUMO

Este artigo discorre sobre o pensamento pedagógico de Rui Barbosa expresso em seus pareceres sobre a "Reforma do ensino primário e várias instituiçóes complementares da instrução pública"e outros trabalhos extraídos de suas Obras Completas. Trata-se de indagarqual era a perspectiva do ideário liberal sobre educação em finais do Segundo Império no Brasil e qual a possível repercussão desse debate para as discussões travadas sobre educação durante a vigência da Primeira República. Palavras-chave: Escola; Educação; RuiBarbosa.
ABSTRACT

This paper proposes to analyse some aspects of the educational discourse taking place in Brazil at the end of $19^{\text {th }}$ century. It seeks to identify the guidelines by means of which the new ideal of nationbood and the social place to be occupied by the school were shaped. Rui Barbosa proposes the indispensable alliance between the school and the vote. He believed it was really necessary to organize the liberal society.

Keywords: School; Education; Rui Barbosa.

Apreocupação com a instruçãopopular como meio de babilitação doshomens para a função de cidadania remonta, no Brasil, pelo menos às discussóes da Constituinte de 1823. Parece curioso que, em um império de súditos, já se advogasse um sistema de idéias cujo alicerce vinha pautado pela irradiação do movimento da ilustraçãofrancesa no sentido da universalização dos direitos. Um estado monárquico, mas constitucional; e, nele, a feição de legitimidade outorgada pela expansão das escolas. Ocorreu entretanto que, entre as aspirações democratizantes dessa Assembléia, 
os interesses "moderadores" do Imperador e a sempre constante epresente pressáo das elites aristocratas do país, abistória presenciasse o conflito e a vitória do atraso e das soluçóes pelo alto de gabinetes. Em matéria de educação, Celso Beisiegel demonstra, aliás, que a despeito de o projeto de 1823 ter sido mais avançado do que o texto promulgado em 1824, ambos se restringiam, por força das circunstâncias de uma sociedade excludente, escravocrata e estamental, a delegar direitos apenas aos bomens livrese de posses, protegidos que eram pelo sistema censitário imperial. Além dos limites manifestos quanto a essas primeiras idéias de educaçáo popularno Brasil, oautor aponta a ineficácia dos preceitos constitucionais. Segundo ele, tal dissonância entre "o discurso exuberante e a ação acanbada" seria constitutiva de um longo percurso referente às relaçóes entre as idéias pedagógicas preconizadas no país e as instituições educacionais nele imperantes. Em função disso, tanto o projeto dos Constituintes de 1823 - que previa o estabelecimento de "escolas primárias em cada termo, ginásios em cada paróquia e universidades nos mais apropriados 254 lugares"-quanto a Constituição aprovada em 24-cujos dispositivos acerca da instruçáo limitavam-se à garantia da gratuidade e ao ensino de elementos de ciências e belas-artes em colégios e universidades-, ambos representavam um ideário transplantado com vista à configuração de um novo modelojurídico e político da sociedade. Noparecer de Beisiegel:

Tendencialmente, a sociedade capitalista moderna estaria avançando no sentido da afirmação do direito de todos os indivíduos a um número crescente de anos de escolaridade è̀ igualdade de oportunidades de acesso de todos à totalidade das possibilidades educacionais existentes. Uma vez idealmente realizada, esta bipotética igualdade de oportunidades de acesso aos diversos degraus do sistema escolar implicaria a emergência de um novo padrãode desigualdadessociais, diferentes das desigualdadespróprias à sociedade de classes. A abertura de oportunidades de acesso à educação-ou, em outras palavras, a igualdade de possibilidades de plena realização das diferenças individuais de aptidóes, interesses e personalidade, traria consigopadróes nãoeconômicos de distribuição dos indivíduos pelas ocupaçóes e posiçóes sociais'. 
Em suma: supunba-se que as desigualdades poderiam ser justificadas à huzde uma diferenciação entre capacidades e talentos individuais. Julgava-se, assim, transfomar a elite econômica e ainda aristocrática em elite cultural. Parece-nos que, mais dojustificar odescompasso entre a produção e a circulação entre as idéias, pelo velbo argumento de que as mesmas não teriam se originado no Brasil, cabe fundamentalmente procurar a compreensão dos meios de ajuste encontrados por aquela produção teórica quando adequada à estrutura social e política do país naquele instante ${ }^{2}$. Nesse sentido, de fato, constata-se o abismo entre as idéias e as realizações pedagógicas dos tempos monárquicos, já que as crenças e profissóes de fé, difundidas no ambiente político em relação às possibilidades regeneradoras da instrução, não foram, de imediato, transformadas em concretizaçóes efetivas de ampliação da rede escolar no país. O trabalbo de Beisiegel demonstra que os projetos pedagógicos no Brasil, desde os primórdios de nossa Independência, são antes antecipaçóes arbitrárias do poder público-e reduzidas, talvez por isso à letra morta da lei-do que tradução concreta das aspiraçóes dos habitantes em demandas populares por escolarização.

Reiteradamente reafirmadas, e incorporadas, já a esta altura aosprincipaistextos legais da nação, as idéias de educação dopovo davam forma a um imperativo educacional, um imperativo ainda não atendido pelas administraçóes do Império ou das províncias, mas nem por isso menos válido para os intelectuais e legisladores da época. Já em suas origens, as idéias de educação popular colocavam-se, assim, muito além das possibilidades de realizaçáo da sociedade brasileira - mas, por isso mesmo, desde estes primeiros tempos, sob a influência destas idéias, a ação educativa do poder público no campo do ensino popular colocou-se sempre à frente dassolicitaçóes educacionais da comunidade ${ }^{3}$.

Opróprio Ato Adicional de 1834, garantindo para as assembléias provinciais legislarem sobre instrução pública e promovêla, em parte acarreta-com essa tônica descentralizadora-uma dualidade de competências entre União e províncias no que diz respeito à faculdade de legislar sobre o ensino. No entanto, restrita àsgarantias liberaisformais, nãobouve a partir dessa iniciativa 
projetossignificativos de expansão da tarefa do estado monárquico no ensejo de elevar o nível cultural da populaçấo. Frente a isso, pareceque, à época, odescaso pela educação era ainda manifesto.

É nofinal do século XIX que o pensamento liberal brasileiro intensificará seus propósitos com vistas a colocar o Brasil no nível das naçóes mais avançadas, superando o atraso cultural que, então, já nos perseguia. Como sugere Beisiegel, dos projetos de reforma do ensino, do aperfeiçoamento proposto para a instrução, almejar-se-ia então criaruma nova mentalidade social, à altura das exigências do tempo. Procurando esculpir a seu modo ofuturo, bomens que se entendiam como dignos expoentes da ilustração brasileira previam rumos alternativos a serem trilhados pelo país e, nele, bomens transformados por um projeto pedagógico organizado com ofito de promover o desenvolvimento da nação. É como se ofuturo que se desejava construir devesse, preliminarmente, ser afirmado no texto da lei. Nesse sentido, o descontentamento com a situação presente se consubstancia em projeçóes referenciadas por realidades alheias. A educação transformada passa a se impor às imaginaçóes como componente imprescindível da utopia. Essa é a caracterização de Beisiegel sobre os vínculos e desconexóes entre a sombria realidade dos parcos estabelecimentos de ensino no Brasil imperial e as imagens luminosas de uma naçáotransfigurada, considerada por suas elites como estando à altura dos povos civilizados.

Como indica o trabalbo de Bresciani, a trajetória republicana no Brasil parece carregar consigo apropriaçóes indevidas do termo democracia, subordinando-o, muitas vezes, a premissas exteriores ao pensamento democrático. Os próprios monarquistas, no outono do império brasileiro, apoiaram-se no ideal democrático como sustentáculo de iniciativa de suas políticas públicas, desenvolvendo, assim, também eles, projetos para reformulação e extensão da rede de escolas no país. Nessa direção, fazia-se necessário, como denota claramente Rui Barbosa em seus Pareceres sobre Instrução Pública, datados de 1882, disseminar as luzes para desterrar a ignorância, para babilitarcidadáospara seus efetivos direitos em direçáo ao aperfeiçoamento das novas instituiçõesjurídicas. 
A emergência do partido Republicano (1870)-como destaca otexto de Bresciani-referenda a idéia de que a instruçãopopular seria estratégia imprescindível à marcha do progresso. Havia necessidade, naquele momento bistórico, de, transformando os súditos em cidadãos, conferir significadoà idéia de nação. Oideário republicanojá acena, pois, com a irredutível incompatibilidade entre um sistema verdadeiramente representativo e a ignorância popular, até então voluntariamente mantida por uma ordem social que prescindia da "vontade geral" para agir com total onipotência sobre a "coisa pública". Havia, nessa perspectiva dos republicanos emergentes, um antagonismo essencial entre realeza e povo, a partir do qual a governabilidade da ordem monárquica se tornava gradualmente instável e sujeita a perturbações. Opovo deveria ser assim, sutilmente, educado para a vida democrática; na escola eram depositadas as esperanças de preparar essa sociedade parao novo tempo no qual haveria efetiva demanda do exercício dos direitos políticos. Os republicanos concebiam-se como agentes portadores das luzes da razáo, no advento de um novo modelo inspiradoempaísesmais adiantados.

Oobjetivo a atingirpassa necessariamente pela "consciência" do indivíduo, e por sua forma coletiva, a "consciência nacional”. Na verdade, a açáobumana junto ao processo de desenvolvimento da "força latente" que existe em "todo bomem" representa o elemento catalisadorque pode apressar ou retardar a "irresistível colaboração do espírito com a verdade" sem contudojamais conseguir interromper ou inverter sua direção. No entanto, a fala republicana parece não deter a certeza de que esse processo se realize sempre no sentido esperado, pois ela alerta para a existência de duas alternativas, o amesquinhamento "até a materialidade do instinto" e a subida até a “claridade da razão”. Sãoos "princípios do bem" contrapondo-se às doutrinas do mal, os dois últimos elementos opostos e latentes em tudo o que ébumano, aquilo que constitui a marca diferenciadora dabumanidade emmeioaosanimais.

A responsabilidade pedagógica do Estado se alia, pois, às necessidades ditadas pelas exigências do tempo, de acordo com a marcha inexorável dos povos rumo a um processo de progressivo aperfeiçoamento trazido, ao que se supunba, pela luzes da 
civilização. Ocorre, entretanto, que essa idéia de uma nação a ser construída náo constitui privilégio exclusivo do pensamento republicano, já que elementos ilustrados da elite do país apontavam no Parlamento que os males a serem erradicados do território brasileiro originar-se-iam antes nos bábitos e na educação, para, como decorrência, fixarem-se posteriormente nas leis e nas instituições. É assim que a mística da nacionalidade vem acompanbada porum projeto pedagógico que traduzia, enquanto tal, a suposta feição de um caráter nacional a ser impresso no povo brasileiro. Sem dúvida, o séculoXIXpresencia a expansão da escola pública, universal e gratuita nos países desenvolvidos, nos quais a eliminação do analfabetismo significava, de uma certa forma, qualificação para otrabalbo técnico industrial; por outro lado, cabe lembrar, em grande parte dos países avançados, havia uma verdadeira demanda correspondente às formulações de sólidas políticas que organizavam redes nacionais de escolarização pública. O Brasil de então náo correspondia, evidentemente, a tal realidade economicamente avançada. Formas arcaicas de produção, abundância de mão-deobra e baixa densidade demográfica e de urbanização representavam a delimitação de nossa estrutura agrário-exportadora na virada do século. Mesmo assim, já se cogitaria, no próprio sistema monárquico, sobre a criação da educação industrial como necessidade intrínseca a o desenvolvimento do país. Acerca disso pode-se tomar Rui Barbosa como um exemplo da ilustração liberal brasileira na rota do desenvolvimento do país. Em seus pareceres sobre a reforma do ensino primário, o autor apresenta nitidamente sua concepção sobre o terreno a ser cultivado. A prosperidade da nação deveria se aliar ao trabalbo; e este, a seu corolário intrínseco: a instrução popular.

Que estamos destinados a ser, por muito tempo, uma nação "especialmente" agrícola, é uma verdade óbvia, que ainda ninguém controverteu. Mas que devamos ser um país "exclusivamente" agrícola, é suposição que não tem sequer senso comum. Entretanto, para ela insensivelmente pende, de fato, o exclusivismo dos que esquecem a necessidade do trabalbo industrial, como elemento imprescindível de civilização e de riqueza, ainda entre ospovos lavradores. Essa parcialidade errônea, ininteligente, cega, 
de certos amigos, mal aconselbados, irrefletidos, ou míopes, do interesse agrícola, faz pensar na fatalidade que condena os espíritos de idéias preconcebidas e absolutas a náo verem senão a face das questóes que os absorve. Homens às vezes de levantado entendimento incorrem nesses vícios de apreciação ${ }^{\sigma}$.

Defendendo, à luz de tais pressupostos, o ensino industrial, Rui Barbosa justifica que tal instrução, preparando o indivíduo para o trabalho, traria, também a ele, benefícios individuais'. A instruçáo popular é tomada, em tal perspectiva, comotarefa urgente a ser assumida pelo poder público. Ao que parece, nesse início da década de 80, o autornáo se contrapunba à monarquia, ainda que se apresentasse já como abolicionista. Entretanto, todo o conjunto das sugestóes por ele efetuadas no sentido de debelar a ignorância do Brasil pode ser apontado como antecipação de um novo sistema no qual a cidadania inevitavelmente estaria fadada a ser o elemento fundador. Daí a crítica impiedosa ao Estado que relegava a educação popular, sem dar a formação do povo sua devida prioridade. No parecer de Rui Barbosa, bavia de imediatamente se passar a oferecer instrução, sob o custo de-em não se fazendo isso-abdicar-se irremediavelmente da rota da democracia e, portanto, em seu entender, da própria trilha da civilização, tal como esta se teria constituído pelo exemplo dos povos europeus. Ainda que náo passasse de uma declaração de intençóes na ausência de concretização de um verdadeiro sistema de educação nacional pelo qual fossem efetivamente preparadas as forças populares, as forças do país, inúmeros trabalbos mais recentes têm sido unânimes em concordar que os pareceres de Rui Barbosa representam para a História da Educação talvez o primeiro grande diagnóstico da situação real do ensino no país.

OEstado ainda não aprendeu outro meio de acudir as crises e remover os déficits senáo endividar-se e tributar. Solicitai dinbeiro para o ensino e vereis apurarem-vos migalhas. Em palavras, todas as homenagens à instrução popular; nosfatos, uma avareza criminosa. Não é a terra, nem o numerário, o que constitui a riqueza das naçóes, mas a inteligência do bomem; eis a lei fundamental da verdadeira ciência das finanças. Aqui, porém, se a teoria admite, a prática a rejeita. Oorçamento do ensino cresce gota 
a gota: tem direito a milhares de contos, e recusam-lhe centenas de mil réis. Para tudo se contraem empréstimos e abrem operações de crédito; para a educação do povo nunca! Não se convencem de que a instrução não tem preço ${ }^{8}$.

Como relator da Comissão de Instrução Pública da Câmara dos Deputados em 1882, Rui Barbosa efetua rigoroso estudo da situação escolar do país à época, relatando, em seu parecer e projeto de reforma do ensino primário, abrangente análise tanto dos princípios pedagógicos quanto de uma descriçáo do cotidiano escolar, de precioso conteúdo para se bistoriar a mentalidade educacional da elite ilustradabrasileira quanto aos esforçosempreendidos no sentido de elevar o país ao nível das naçóes esclarecidas. A preocupação primeira de Rui Barbosa, enquanto político interessado em questóes pedagógicas, deriva da constatação de impossibilidade de competição entre o ensino brasileiro e o dos povos avançados, donde o desdobramento lógico de nossa inferioridade cultural. Em um povo no qual o analfabetismo decresceria de forma assustadoramente lenta, nada se poderia esperar além

260 desse absoluto despreparo no qual, segundo o autor, submergia a mocidade. Nesse sentido, ele denuncia o peso da ausência de método e de racionalidade no ensino como substrato primeiro de escolas cuja própria arquitetura se revelava imprópria para abrigar as características infantis.

Apropósito das escolas modelo que, em suas palavras, "ornavam alguns pontos da cidade”, Rui Barbosa classifica-as como “ostentosas e estéreis exceções”, mas em cujo interior ainda subsistiam métodos arcaicos e inadequados de instrução. Triste realidade aquela-dizia ele-principalmente se, pelas casas escolares, fosse possível avaliar o "sentimento de um povo". Do ensino distribuído à infância, eis o povo que se modela:

Do material técnico de ensino existem apenas os elementos mais rudimentares e os tipos mais primitivos. Tudo está revelando o domínio absoluto da palavra autoritária domestre, ou dasfórmulas ferrenbas do compêndio, servidas pela memória passiva do aluno. Nada fala aos olbos da criança: nada lbe provoca os instintos de observação, nada lhe desperta a espontaneidade; nada a póe em contato com o mundo e a natureza. Nem cartas murais, nem coleções de objetos para as lições pelo sentidos, nem sequer os 
mais grosseiros meios de experimentação. A inviolabilidade das paredes é religiosamente observada, em alguns desses estabelecimentos, graças a recomendaçóes estritas, que apenas se poderiam compreender, se víssemos provida a escola de porta-cartas, estantes móveis ou outros meios próprios de apresentar aos alunos os quadros, as estampas, os modelos precisos. 'O quadro preto', diz um dos mais eminentes pedagogistas americanos, 'é tão necessário ao mestre como o arado ao agrícola, a plaina ao carpinteiro, ou a lanceta ao cirurgiáo. Importa alargá-lo pelo menos, a toda a extensão do estrado de onde fala o mestre e multiplicá-lo por todos os claros de que se possa dispor. Náo sei de professor que já se queixasse de excesso de pedra".

Adenúncia extrapola, portanto, a vagueza de consideraçóes metodológicas, sempre tão caras ao discurso pedagógico corrente. Odebate, aqui, remete-se fundamentalmente à política. Aquela escola pautada quase exchusivamente na memorização, nãoconduzia o estudante a uma descoberta de suas potencialidades, de seus talentos, de suas vocações. Não incentivando no discípulo a abertura de seu spóprios caminbos, aquilo que seria efetivamente uma ampliação permanente do território da cultura e do aprendizado, odesejo pelo conbecimento, a curiosidade intelectual. Nada disso. A escola brasileira doXXX parecia sequer desejar desenvolver a capacidade de crítica pelo exercício sistemático do pensamento cuidadosamente ancorado no recurso ao legado de uma cultura letrada, posta como universal. Pelo contrário, aquela escola, restrita a tão poucos, carecia da lucidez para ooficio de preparar bomens para a vida social, em toda dinâmica e viço peculiares a esta. Homens sem perspicácia, incapazes de pensar. Esse seria o produto de uma instrução opaca, fator de descrédito do país perante o mundo. Assim julgava Rui Barbosa.

A crítica a onsino religioso vem fundamentalmente atrelada ao contraponto da liberdade de ensino. Não se pretende extinguir este ou aquele ramo de instrução. O que se deseja, isso sim, é dar laicidade à escola pública; até porque, sendo nela muitas vezes o ensino religioso ministrado por leigos, estes não teriam a qualificação necessária para fazê-lo. Expondo sua frontal discordância no que tange à liberdade quanto à colaçáo dos graus, o autor sugere que apenas ao Estadofosse conferido esse direito. Remontando a exemplos estrangeiros e a reformas efetuadas em 
inúmeros países, o autor se remete às obras de Comte como inspiração dos ideais laicos em matéria de instruçãoe, mais doque isso, de separação entre a Igreja e o Estado. Mesmo assim, sem mediar a contradição entre seu declarado liberalismo e a constante recorrência a tais referências positivistas, Rui Barbosa declara-se adepto de um ensino liberal, o único que -segundo ele-seria capazde superar a "anarquia reinante" nas matérias de educação. Buscando o veio democratizante de premissas que estavam já em Condorcet, nos debates legislativos da Revolução Francesa (1792) apretensão, com isso, seria a efetivação de uma verdadeira rede de escolas públicas, sustentadas e difundidas pela ação estatal. Aliberdade de ensino depara-se, nesse aspecto, com seu limite:

Levarei adiante a minha crítica: direi que a liberdade absoluta da instrução pública, se por algum decreto se pudesse proclamar, seria 'daninha' eviria a dar em arma perigosa nasmãos dopartido em cuja opinião é demasiada a presteza com que seguimos a via doprogresso... Logo, que se há de fazer para melhorar a instrução pública?... Atualmente, querna França, quernas demais partes da Europa, só nos é dado pregar e esperar. Mas no dia que as vicissitudes sociais constantemente nos antolham, no dia em que triunfar algures o partido democrático, a que me bonro pertencer, -que tentativa ensaiaremos para iniciar um ensinoliberal? Se me tocasse aconselbá-lo, o meu conselbo seria que não se proclamasse a liberdade sem limites de ensino; 'que se não abstivesse de todo no que interessa à instrução pública'; a menos que, daqui até lá, o mundo adiantasse um imenso passo na vereda do progresso. Longe de mim, está claro, ô̂nimo de tolher a ninguém odireito de professar suas idéias e vulgarizá-las. Assaz civilizado é o nosso século, para permitir, a este respeito, a mais larga tolerância. Queroapenas dizer que, a par das escolas livres, que se formarem, ao lado do ensino católico, protestante ou espiritualista, cuja proteçãofôra inútil tentar, 'necessário será estabelecer escolas oficiais', organizaruma instrução mais liberal do que quantas ser possam, e nutrir, a expensas do Estado, uma instituição, que só em condiçóes tais não terá que se arrecear da concorrência. Em suma, só almejo a liberdade de ensino, até onde chegar a liberdade, franqueada a todas as crenças, de se manifestarem, a todos os partidos, de fundarem escolas, e não como abstenção completa do Estado em todas as questões que toquem ao domínio da instrução geral. 'Oensino oficial náo deve embaraçar o ensino livre; mas, por enquanto, $o$ ensinolivre não poderia suprir a falta do ensino oficial ${ }^{10}$. 
o pressuposto de tal convicção deriva do suposto de que seria a ignorância das camadas dirigentes brasileiras fator propulsor dos males de que a nação se queixa. Constituir o ensino liberal náo seria, contudo, tarefa, para qualquer um; era antes o dever urgente dos estratos esclarecidos da população, na visáo do Parlamentar, os únicos capazes de efetuar um projeto de tal responsabilidade social e política. Alógica era, portanto, a de reconbecer o povo como um "outro", a quem deveriam ser feitas imediatamente algumas concessóes. O resultado de um movimento como esse, empreendido-no projeto liberal de Rui Barbosa-pelas elites políticas e econômicas no país, seria o de precaver-se contra os perigos inscritos em uma democracia nominal, que, mal compreendida, poderia vir a desgraçar opaís. Citando Washingtom, Rui Barbosa proclamava a instrução como a mais sólida base de prosperidade pública. Citando Monroe, atestava que o desenvolvimento da inteligência nacional constituir-se-ia medida máxima de fortalecimento e preservaçáo da liberdade. Dessa maneira o autor deduz que, consultada a bistória, percebia-se que as "naçóes que melbor asseguram a sua supremacia são as que mais fazem por derramar a instrução".

Da faculdade de ler e de pensar, decorreria a utilidade social da instrução como uma diretriz inestimável no encaminbamento das mais candentes necessidades nacionais. Evidentemente a escola é tida, sob tal abordagem, como instituição voltada para as garantias da extensáo progressiva, gradual, contida e vigiada da vontade popular. O contraponto da reforma é sempre a revolução. Em um país cuja tradição “cordial”'orgulba-se das transiçóes pelo alto, o rumo diretor deveria ser a reforma ordenada das instituições. "Mãe da servilidade e da miséria", cabia por essa lógica, que o Estado se antecipasse na "erradicação da ignorância" - ameaça por excelência contra a legalidade constitucional e a liberdade da nação. No parecer de Rui:

Oquadro de esmagadora tristeza que levamostraçado (...) deve acordar na alma dos patriotas, de todos os homens de bonra, de todos os amigos deste país, a energia das grandes resoluçóes, sopitadas pelos nossos hábitos de hereditário desleixo. Uma reforma radical do ensino público é a primeira de todas as 
necessidades da pátria, amesquinbada pelo desprezo da cultura científica e pela insigne deseducação do povo. Sob esta invocação conservadores e liberais, no Brasil, podem reunir-se em um terreno neutro: o de uma reforma que náo transija com a rotina. Num país onde o ensino não existe, quem disser que é 'conservador em matéria de ensino' volteia as costas ao futuro e desposa os interesses da ignorância. É preciso criar tudo; porquanto o que aí está salvo raríssimas exceçóes, e quase todas no ensino superior, constitui uma perfeita humilhação nacional" ${ }^{11}$.

Absolutamente entusiasta do projeto da Terceira República Francesa, especificamente pela atuação de seu então Ministro da Instrução Pública -Jules Ferry-o autor indica que, sob o exemplofrancês, inúmeros países considerados avançados despendiam elevadas somas em empreendimentos relativos ao ensino. Apostar no ensino como investimento coletivo no futuro era portanto sinal da perspicácia política e orientação administrativa, necessárias para impulsionar a grandeza do Estado. Nenbuma dificuldadefinanceira poderia, com justiça, ser invocada comoálibiparao náo cumprimento daquela que, noparecer do político e do intelectual Rui Barbosa, punba-se na ocasião como um dos deveres mais candentes da esfera pública: a instrução popular.

À luz de tais consideraçóes preliminares, otexto alerta os contemporâneospara a insuficiêncialegal da garantia da gratuidade de ensino-prevista na constituição monárquica-, já que a mesma, sem se associar aoprincípio da obrigatoriedade escolar, tornar-se-ia letra morta do texto jurídico. Se a instrução obrigatória pressupunbancessariamenteagratuidade-argumenta oautor-estadeveria virobrigatoriamente acompanbada pelo ensinoobrigatório

Mantido um regime de instruçáo facultativa, ocorreria de fato uma proteção legal e institucionalizada do direito de ser analfabeto. Sob a égide da ignorância, o arcaísmo de nossos dispositivosjurídicos contemplavam a auto-perpetuação do próprio obscurantismo. Se tal análise demonstra, por um lado, o reconbecimento do dever do Estado nos assuntos relativos ao direito subjetivo ao aprendizado, por outro lado bá, no texto, evidente responsabilização dos pais. Em certa medida, entendia-se ser a a ausência de zelo dos pais um fator a mais para agravar o descolamento entre o mundo da escola e o mundo do trabalbo, sendo que as 
crianças pertencentes ao último invariavelmente abandonavam as fileiras escolares. Obrigar a instrução elementar não era ato com que se pudesse pois, negociar: mas, antes, necessidade social e dever irredutível de justiça bumana.

Como maior evidência da eficácia de tal proposição, o autor recorda que tal discussão estaria absolutamente superada nos recantos civilizados do mundo, nos quais já não baveria qualquer discordância acerca da legitimidade jurídica da instruçãoobrigatória. A lógica do discurso faz-se, entretanto, capciosa justamente ao enunciar oproblema sob o espectro dessa tônica exclusivamente legal, cuja própria coerência argumentativa exchu, por si, todo um feixe de questóes estruturais advindas da própria lógica de exclusóes presente em qualquer sociedade de classes. O direito subjetivo ao intelecto parece ser princípio inequívoco da própria condição bumana de existência. Sendo assim, por que não entrelaçálo a seus aliados naturais que, porvezes, inclusive, antecedem tal formação? Onde situar, por exemplo, os direitos sociais sendo que só eles poderiam assegurar o pleno desenvolvimento da vida bumana? O sujeito privilegiado do discurso liberal de Rui Barbosa surge, nesse sentido, pela ausência: a própria liberdade parece restringir-se quase exchusivamente à liberdade civil, pela mediação da lei. Havia um esboço de nacionalidade a ser tecido. Neste, cumpria instruir para construir. Oprincípio diretor dessa redução do social ao legal residiria, provavelmente, no recombecimento da propriedade como um dado inquestionável que estava, enquanto tal, suposto na própria construçấo do discurso. Ao governo competia então proteger a propriedade contra quaisquer riscos, quaisquer ameaças. Se a ignorância reinante representava na ocasião um óbice para o desenvolvimento e para a modernização do país, aceitava-se fazer concessóes. Tal justificativa, entre outras, é indicada pelo próprio Rui Barbosa, quando este reconbece como obrigação indiscutível do governo o atendimento de demandas sociais elementares para a estabilização da ordem democrática. Ocorre, no entanto, que para a própria legitimidade jurídica dessa gênese do liberalismo republicano no Brasil, oquadro desolador da miséria reinante exigia providências institucionais. 
As esperanças de transformação e superação do arcaísmo rumo à modernidade estrangeira sáo depositadas, em grande parte, nas possibilidades da instrução popular. Tal medida poderia, quem sabe, alçar opaís à altura do universo civilizado. Aísim oplanojurídico teria os alicerces imprescindíveis parajustificar as desigualdades pela diversidade dos talentos. Rui Barbosa verificava os obstáculos institucionais à edificação do modelo social pretendido. Talvez por essa razão ele tenha, com tanta veemência, condenado também o modelo de escola existente, expondo, a partir de sua denúncia, um projeto alternativo, para organização de um verdadeiro sistema escolar condigno com o rumo propugnado para o desenvolvimento nacional. Eis a leitura ilustrada do que fôra outrora o ensino neste país:

Que cena nos oferece ao deixar à aulas, um desses grupos infantis, que, saciados de doutrina cristã, de bistória sagrada, orações e mistérios, desafoga ao ar livre, na verdade expansiva dos instintos poderosos daquela idade, os bons e maus dotes de uma natureza comprimida pelos exercícios da escola mecanicamente decoradora e escrupulosamente devota? Se essas crianças são a imagem desse ensino, com que resultados se recomenda ele? Polidez do dizer, decência do tratar, asseio do vestir, gosto de volver à tarefa diária da escola, respeito mútuo, sentimento do direito albeio, da obediência à lei e da própria responsabilidade, repugnância pelas coisas baixas, benevolência com os pobres, osfracos, os infelizes, os desprotegidos, os pequeninos; é isso, é algum vestígio, algum reflexo, algum germe disso, o que ali se nos revela a cada passo? Não; é, em geral, pelo contrário, a malignidade desordenada, rota ou sórdida na roupa, desbocada na linguagem, brutal nos modos, agressiva, petulante com os indefesos, enojada da escola, destruidora dos livros, provocadora contra os pacíficos, dissimulada na presença atenta do mestre e aproveitadora perigosa dos seus mínimos descuidos: eis o menino desnaturado pelo nosso sistema de instrução ao qual se alguma lacuna se nota, por certo náo éo desprezo do catecismo, para cujo ensino superabundou sempre zelo entre os nossos minguados educadores. Eis o produto da escola onde sobra a devoção e falta o professor ${ }^{12}$.

Da veemência da crítica derivaria, por decorrência, a defesa de uma escola laica sob controle do Estado. Instituição temporal, náo competiria à escola ministrar o ensino religioso. Contudo, este poderia ser oferecido por representantes das várias crenças 
no reduto da casa escolar, masfora do borário regular e, evidentemente, sem qualquer vínculo com o currículo oficial. Abertas as portas da escola, mesmo assim o autor localiza as diferentes igrejas como instâncias privilegiadas para a tarefa de "conversão". Objeto de controle público, à escola cabia ausentar-se da "fiscalização onipotente da sotaina", já que nenbum direito de consciência religiosa pode ou deve se sobrepor às imperiosas exigências daquilo que o político nomeava "consciência filosófica".

Faz-se necessário então compreender a acepção de Estado que era apresentada nos pareceres de Rui Barbosa. Artifício imposto pela vontade humana pensada em seu coletivo, o Estado é tomado, fundamentalmente, como a instância mediadora entre as várias correntes de pensamento, as várias opinióes, os vários cultos, que comporiam os elementos constitutivos do conjunto da nação. Nessa perspectiva, Rui Barbosa declara ser totalmente contrário a quaisquer mecanismos de promoção do "Estado ao papel de mentor do espírito humano e pai dos pais de família”. $O$ patamar da inteligibilidade do Estado não é posto, por essa via, em nenbuma causa superior, à parte dos desejos humanos. $E$, inclusive, à luz de tais premissas, que o autor sente-se muito à vontade para defender intransigentemente a liberdade e, inchusive, a liberdade da desigualdade, já que a radicalização do ideário de igualdade bumana poderia abolir as "diferenças individuais", contidio sine qua non da liberdade.

Para trabalhar o papel do Estado na consolidação de uma sociedade moderna e avançada, Rui Barbosa toma a referência da Revolução Francesa como matriz do debate contemporâneo sobre a democratização do ensino. Caracterizando o projeto pedagógico de Condorcet como o exemplo mais louvável de ensino democrático, oautor aponta suas severas restriçóes ao planojacobino de Lepeletier, que seria, na Convenção Francesa, defendido por Robespierre. Para Rui Barbosa, os dois projetos se contrapunbam e se excluíam um ao outro enquanto prospectos de formação bumana. Contrário ao monopólio do Estado em matéria de educação, Rui Barbosa salienta que o poder público deveria, sim, assumir sua tarefa de irradiador das luzes contra as sombras do obscurantismo. Ocorre que essa multiplicação do conbecimento secu- 
lar se realizará ensinando e nunca inibindo de ensinar os inimigos das luzes.

Assim compreendida há, nessa liberdade proclamada, mais do que a manifesta tendência para a desigualdade. Há um suposto lugar social privilegiado por meio do qual os bomens são classificados de acordo com sua indole: brandos ou perigosos, livres ou fanáticos, racionais ou supersticiosos, sábios ou ignorantes... Cumpriria à elite nivelar pelo alto essa sociedade. Havia, sem dúvida alguma, em tal orientação, uma acepção evolutiva de civilização, em função da qual ogrande árbitropara qualificaçãoda verdade e do erro seria o conbecimento científico. Daí a importância atribuída à transmissáo desse saber cumulativo no ideário de esperanças com que se fabrica a nova escola. A propósito desta, Rui apresenta, então, os fatores envolvidos como possíveis fontes de erro do ensino ministrado. Em sua análise, sãovalorizadas fundamentalmente a aptidão intelectual do mestre e as crenças e os valores a serem transmitidospelosprimeiros educadores como seiva primordial para formação de coraçóes e de espíritosjustos, democráticos e talentosos. Todos os outros elementos derivariam, ao fim e ao cabo, dessa matriz primeira da socialização escolar.

Para o autor, cumpria criar o método ${ }^{13}$. No Brasil, de maneira geral, a educação calcada exchusivamente na memória do educando tomava a criança náo como alma a ser esculpida mas como tábula rasa, na qual a verdade poderia ser sumariamente impressa. Os hábitos de tal escola necessitavam, pois, de urgente alteração. A reforma escolar brasileira exigia, diante disso, a transformação da mais endurecida de todas as rotinas - a rotina pedagógica ${ }^{14}$. Para Rui Barbosa, a escola, tal como se apresentava à época, agiria no sentido de "deturpação da bumanidade", assentada que estava exclusivamente no espírito do mestre, ignorando a energia individual o os esforços íntimos despendidos pelo educando. Para se alterar com eficácia tal situação indesejável, deveria baver indiscutivelmente um movimento de reorganização da prática institucional imperante com vistas a identificar, explorar e estimular as aptidóes individuais do aluno.

Tomando por referência os trabalhos de Froebel e Pestalozzi ${ }^{15}$, o autor combina aquela perspectiva de ensino integral com a es- 
perança de tornar da escola uma verdadeira recapitulação, no espírito do aluno, do desenvolvimento cumulativo da bumanidade. Nessa conjunçáo entre o talento individual e o talento da espécie, a meta seria percorrer, por meio do próprio currículo escolar, o cabedal de conbecimento bistoricamente produzido pela civilização ocidental. Os vellhos programas carregavam consigo males intrínsecos, devendo, pois, ser repudiados. Contrariando a necessidade orgânica do desenvolvimento infantil, o ensino verbalista deveria ser, pois, superado. A “tirania dofraseado"'ocultava a criança do mundo dos fatos, aquele da realidade que existe para além do ruído das palavras. A reflexão, nesse aspecto, só ganbaria significado quando aliada à observaçáo. A contemplação do mundo natural deveria, por decorrência, tornar-se ponto de partida do processo de aprendizado da criança. Político, Rui Barbosa alicerçava seu parecer em idéias dos mais renomados educadores da bistória da Pedagogia:

Estudai os processos da classe de primeiras letras entre nós, e achareis em espírito e ação o mesmo regime educativo contra o qual, bá mais de três séculos, se revolta a inteligência bumana: o ensino vão, abstrato, morto, de palavras, palavras, e só palavras. Já Lutero se insurgia contra esses métodos insensíveis à verdade rudimentar, evidente como a huz meridiana, de que a compreensão do vocábulo bá de resultar da compreensáo da coisa. 'A arte da gramática', discorria, com ovigor da sua inteligência privilegiada, o grande reformador, indica o nome e a acepção das palavras; mas primeiro se bá de conbecer a coisa, ou a sua razão. Quem quer que deseje aprender, e pregar, comece, antes de falar das coisas, por escrutá-las(...). Trivialidades que a nossa pedagogia ainda nãoaprendeu.

Proscrevendo da ciência os ídolos chamando-nos à investigação metódica da natureza viva, traçando o caminho ao conbecimento do homem e do universo, Bacon lançou o germe da 'pedagogia realista' (...) da qual decorrem todos os métodos modernos de ensino, da escola à universidade (...)

(...) Comenius (Komensky), um dos mais extraordinários vultos em toda a bistória da pedagogia, esse poderoso espirito que as autoridades de hoje apontam como o primitivo criador do método intuitivo, embebia absolutamente as suas idéias de educação popular nos princípios da grande renovaçáo baconiana: a condenação do escolasticismo, a volta à natureza ${ }^{16}$. 
O princípio desse novo modelo educacional aqui proposto residia então na defesa da intuição do aluno como recurso indispensável para overdadeiroaprendizado. À ciência cabia extrapolar o livro e valer-se dos recursos que a própria natureza oferece: 0 mundo moderno era, aliás, o mundo de Galileu, não maiso mundo calcado sobre o paradigma aristotélico. Com tal orientação, a instruçãotransformada conseguiria atuarnossentidos, na imaginação e, por essa rota, fixar-se na razão. A apreensão pelos sentidos, na mente infantil, precede o entendimento da razão. Essa seria a bipótese básica, de alguma maneira, berdada das leituras de Rousseau efetuadas à época. A partir dela, o autor discorre sobre propostas metodológicas específicas para cada área do conbecimento bumano, citando, na maioria das vezes, autoridades pedagógicas consideradas insuspeitas.

Revela-se bastante nútida a correlação estabelecida entre instrução e virtude: a escola como agência de moralização. Indissociável do cultivo ético, a tarefa do magistério torna-se por sublime: prepara sempre as semprejovens geraçóes para virtudes sem270 pre socialmente desejadas. A união essencial entre educação e virtude é manifesta no texto; e dela derivam a percepção dos deveresindividuaise a preparaçãopara a sociabilidade adulta. É como se, na acepção socrática, o conbecimento do bem fosse suficiente para a adoção da vida reta. Esse bem, por seu turno, tem sua origem na idéia da autonomia da moral, como reduto privilegiado inequívoco que se torna imperativo categórico da fundamentação norteadora dos costumes, sem que tal dimensão moral estivesse associada a qualquer vínculo religioso.

Transpondotal ideáriopara a educação, supõe-se que "a influência melhoradora, prosperadora, civilizadora"17 efetuada pela instrução associa-se intimamente ao cultivo das faculdades morais, já que uma das faces da ignorância reside na ausência da percepção do dever. Em tal aliança entre saber e dever - "com seus pressupostos de autonomia do coração e da mente"18 -, o público alvo é considerado idiota; é um povo-criança, ignorante, que necessita, por essa razão, de condutores de sua consciência, tanto intelectual quanto moralmente. Opovo, incapaz de decidir sobre suas próprias rotas, deverá, pois, ser esclarecido por uma 
elite ilustrada disposta a irradiar suas luzes com vistas à prosperidade da nação arquitetada. As reformas sociais representam obra daqueles que falam em nome do povo, nunca porém com o povo. A escola reformada é o antídoto da rebeliáo porque ela trará não apenas o conbecimento, mas as normas de conduta socialmente aceitas. Tal ação moralizadora deve estar contida nas entrelinhas de cada matéria ensinada. À guisa de exemplo, Rui Barbosa declara que, como veículo desse modelo de ensino, um livro de bistória pode ser mais ilustrativo do que um compêndio de ética. Isso porque o sentimento moral seria antes um bábito constitutivo da conduta bumana do que um abstrato rol de regras sucessivamente expostas. São os princípios traduzidos nos fatos da vida que inscrevem na alma as normas da moralidade. Nãoé a moral de cartilha que se almeja alcançar, mas a ética da ação ocorrida nas realidades tangíveis. Mais uma vez, a defesa da escola leiga contra quaisquer pressupostos de beteronomia da moral:

Respirando na atmosfera da ciência, pois, a escola leiga constitui a representação mais influente dessa moralidade superior, que só a tolerância pode alimentar: Reunindo no seu grêmio os futuros cidadãos de todas as crenças, e protegendo contra as prevenções recíprocas a fé de uns e de outros, incute para sempre na substância dessas almas, na essência dessasnaturezas em formação a primeira, a mais bumana, a mais útil de todas as qualidades de uma sociedade civilizada: o respeito à consciência albeia, o sentimento da liberdade de pensar, a fraternidade, a caridade, a estima, entre os conflitos de opinióes que nos agitam, mas não nos devem desirmanar, nem deprimir uns aos ollos dos outros ${ }^{19}$.

Para tal empreendimento, além do caráter pessoal do mestre, o texto apresenta como pilar fundamental a atmosfera moral que deve perpassar todo o ambiente escolar. A cultura ética brota, sob essa perspectiva, muito mais em função do exemplo de conduta reta do que de prescriçóes albeias ao cotidiano. A moralidade havia de ser encarada "como um resultado da ação, náoda palawra; da impressáodramática da narrativa, nãoda árida letra dos enunciados"2o.

Sempre inspirado nos debates travados pela Revoluçáo Francesa no tocante à instrução e no modo pelo qual as discussáo da Legislativa (1792) e da Convenção (1793) vinbam sendo irradia- 
daspelaspráticas desencadeadaspela Terceira Repúblicana França - cujo marco parecia estar posto justamente em sólida e competente reformulação da instrução pública-Rui Barbosa (que assumira os princípios da escola leiga, gratuita e obrigatória) passa a abordar a polêmica questão relativa à coeducação. A exposição acerca do tema principia com as consideraçóes do autor à luz dos argumentos de Condorcet, para quem o ensino misto favorecia a emulação. Rui Barbosa pondera tal convicção, declarando que, se ampliada a todas as idades, a coeducação poderia vir a acarretar mais males do que bens. Segundo a letra do texto, existiriam inconvenientes morais manifestos para reunião de ambos os sexos nas mesmas escolas, principalmente durante o período da puberdade ou, nos termos do autor, "desde oprimeiro alvorecer da adolescência até a completa constituição sexual da mulber”. Diante disso, no parecer de Rui, dos onze aos dezoito ou vinte anos, educarmeninos e meninas "nos mesmos bancos", mediante a mesma organização pedagógica podia implicarmales irreparáveis tanto na constituição do caráter quanto no próprio desenvol-

272 vimentofisiológicofeminino. A suposição implícita a tal raciocínio de ordem biológica resume-se na distinção entre os papéis sociais designados para cada sexo no interior daquele final de século. A mulher poderia até, no discurso, devassar os domínios do entendimento e contribuir para oaperfeiçoamento da espécie. Mas daía obter o mesmo tipo de formação teórica que se oferece ao bomem, havia um salto. Nesse aspecto, o autor explicita:

Nãoé, pois, uma questão propriamente pedagógica a que ora se nos defronta; é estritamente um dos aspectos de uma questão social, sobre cujos termos quase nada podem ser teorias e as reformas: a questão geral das relaçóes entre os dois sexos no seio de um povo dado ${ }^{21}$.

Pelo exposto, e sendo diferentes os lugares sociais reservados a cada sexo em uma sociedade cuja base é, ainda, escravocrata e monárquica, opta-se por uma separação que principiaria já na escola. A mulber deveria receber um preparo suficiente para que fosse ela mesma educadora de futuros bomens; mas nada além disso... Em outras palavras: "obomem é em si e para si, enquanto a mulber é apenas em outro"22. O discurso de Rui, sob esse as- 
pecto, perde a linearidade e a clareza que lhe são característicos e oscila quanto a definir com maior precisáo as fronteiras biopsico-sociais que separariam, por definição, os intelectos masculino e feminino, oferecendo à alma da mulher um feitio diverso da de seu companbeiro. Aqui, revela-se mais do que apenas o tom besitante de um liberalismo excludente. É o problema mais amplo do bistórico trajeto da mulber naquilo que Romano chamou desrazãoocidental:

O medo, opavor da morte em vida, o desespero do lugar comum se desdobram, face ao monstruoso, em delírio povoado por fantasmas. A maneira estranba de corpos e ações impressiona o intelecto pelo artificio da memória e do sonbo. Esmaecem asfronteiras entre consciência e alienação, tempo e espaço, masculino e feminino. As palavras adquirem a superficie singela do fisico, de sons que, reunidos, significam o Nada. Pergunta Hamlet: 'que é um bomem'? Única resposta possível 'a beast, no more'. A razão pode ser dita de muitos modos, bem como a necessidade por ela determinada. Sãotênues os cordóes entre o mais refinado convívio democrático e a violência tirânica dos humanos, sem nenbuma exceção (...) Opróprio diabo teme a racionalidade, quando exercidapara a destruição do Outro ${ }^{23}$.

Ocorre que em toda a preciosa análise efetuada no seu parecer sobre a reforma do ensino primário, Rui Barbosa foi capaz de detectar o poder invertido dessa racionalidade como fator de desenvolvimento de um povo e o seu avesso, o obscurantismo, como era chamado, à época, tudo que, por uma razão ou outra, não se coadunasse diretamente com a lógica inscrita na berança letrada do ocidente. Evidentemente que em uma sociedade cuja transformação envolveria, por si, a ruptura com o âmbito institucional nos moldes como este era posto, havia no reformador, a par da imensa capacidade de avaliação do ocaso de seu reino, o intuito de instrumentalizar o próprio poder público como agente de capitalização das necessidades sociais, tendo porobjetivo proceder a uma cautelosa transiçáo para a modernidade, massem traumase sem violência.

Adepto do abolicionismo, o curioso é que, ao tratar do problema pedagógico, em nenbum momento Rui Barbosa aponta em direção à queda da monarquia como necessidade bistórica para 
o estabelecimento da escola que propunba. Fundamentalmente, o autor restringe-se a delimitar o rol de suas consideraçóes teóricas acerca do ensino, tomando sempre por referência a aferição do rendimento e do fracasso daquele modelo escolar, além de conjecturar a possibilidade de sua modificação por outro, mais condizente com a urgência da situação do país, que ele supunha em vias de desenvolvimento.

Ao caracterizar a "modernização conservadora" imperante nesse limiar da república brasileira, Marco AurélioNogueira ${ }^{24}$ apresenta o liberalismo da época como a grande "desventura" da nossa nacionalidade. Seu argumento a esse respeito reporta-se à constatação segundo a qual, ancorada em sistema político calcado na excludência, a doutrina entre nós não teria sido suficientemente democrática. Por causa disso, sempre prescindiu do povo que permanecia alheio, sempre exchuído de decisóes vindas "pelo alto".

O mesmo Rui Barbosa que, em seus trinta anos, inquietavase com o problema da instrução, passado quase meio séculofalaria sobre cultura, sobre modernidade e sobre o seu país aos estudantes de Direito do Largo de São Francisco em São Paulo. No caminho, bavia se tornado quase uma entidade intelectual, incontestada quer em ambientes acadêmicos, quer nas agremiações políticas liberais. Suas idéias teriam, comopoucos parlamentares brasileiros, um efeito irradiador de incomensuráveis dimensões. Daí a importância de se atentar para o estudo das reflexóes pedagógicas efetuadas por ele, à luz de sua trajetória política posterior. Sem dúvida alguma, o presente trabalbo náo teria fôlego para tanto. Mas náo se poderia ignorar, em nome da memória das idéias pedagógicas no Brasil, a intensa repercussão que os trabalhos daquele parlamentar tiveram sobre as elites ilustradas brasileiras entre as décadas de dez e trinta. O conjunto da obra de Rui Barbosa-e, nela, a reflexão sobre o ensino-deixou pegadasna tradiçãojurídica brasileira. Nesse rastro, asprimeiras décadas de nossa incipiente república presenciaram a consolidação de um "grupo-geração" cuja plataforma política levaria adiante (desde a fundação da Liga Nacionalista, passando pelo Partido Democrático, pelos movimentos de 30 e 32, até a constituinte de 34) pelo menos dois princípios, a meu ver, fundamentalmente 
democráticos da pregação de Rui: o voto secreto e a expansão de escolas No belíssimo testamento constituído nessa sua Oração aos Moços, o intelectual-educador adverte a juventude quanto ao cuidado a ser tomado para que a lei náo continuasse a ser em nosso país apenas álibi e cúmplice de uma lógica jurídica já desligada de quaisquer compromisso com o campo da justiça:

Ora, senhores bacharelandos, pesai bem que vós ides consagrar à 'lei', num país onde a lei absolutamente não exprime o consentimento 'da maioria', onde são as minorias, as oligarquias mais acanbadas, mais impopulares e menos respeitáveis as que põem e dispóem, as que mandam e desmandam em tudo; a saber: num país onde, verdadeiramente, não há lei, não há moral, política ou juridicamente falando. Considerai, pois, nas dificuldades em que vão se enlear os que professam a missão de sustentáculos e auxiliadores 'da lei'. É verdade que a execução corrige ou atenua, muitas vezes, a legislação de má nota. Mas, no Brasil, a 'lei' se deslegitima, anula e torna 'inexistente', não só pela bastardia da sua origem, mas pelos borrores de sua aplicação ${ }^{25}$.

Monarquista, abolicionista, republicano, crítico da república... um reformador. Um reformista sempre às voltas com a idéia de modificação das instituições. Um político empenbado na edificação de uma pátria. Isso, talvez, era o que ele acreditava fazer, ou o que muitos supunbam que ele fizesse. Sem dúvida alguma, um liberal. Sem dúvida alguma, um jurista. Em tal fronteira, a coragem cívica de apontar lei e escola como necessidades prementes para construção de um país orientado para ofuturo.

Mesmo com o advento da República, continuava evidente que a acepção jurídica de estado de direito não vinha tomada à risca em nossos processos eleitorais, onde a fraude, o voto de cabresto, ofavor, o coronelismo e os currais eleitorais constituíam-se ainda práticas correntes. Comofirmar-se-ia um regime que trai a si próprio berdando práticas e incorporando tantos valores da formaçáo social anterior? Ofoco do pensamento político envolvia, com certeza, a preocupação conservadora com a legalidade, a ordem e o vigor das instituiçóes republicanas. Isso exigia, no entanto, algumas alterações na feição desse sistema. Tornar a sociedade aberta pressupunba a possibilidade de oferecer a todos equivalentes oportunidades no âmbito dos direitos de cida- 
dania. A Constituição de 1891, em plena dinâmica do processo republicano, enfatiza a necessidade de separação entre Estadoe Igreja e o conseqüente afastamento desta dos negócios temporais. Por essa razão, exprime em seu artigo 72 (par. $6^{\circ}$ ) que o ensino ministrado nos estabelecimentos públicos deveria ser necessariamente leigo. Parece revelador ofato de o parágrafo segundo do mesmo artigo-afirmandoque "todos sáo iguais perante a lei"-contrariar explicitamente o artigo 70, que exclui os mendigos e analfabetos, entre outros, do direito à cidadania. Evidentemente, tal contradição nos termos indignaria qualquer democrata. Era necessário, até para prevenir-se contra setores considerados subversivos, criar elementos que permitissem apresentartambém como lícita a ordem legal. No que tange ao ensino, cumpre lembrar que a constituição republicana não apenas deixa de avançar mas, ainda, retrocede em relação ao texto monárquico. Se Rui Barbosa criticava a Carta do Império porque a mesma se limitava à garantia formal da gratuidade de ensino, sem vincular tal princípio às idéias de obrigatoriedade, o que dizer desta-da 276 qual aquele estadista participou-que, pelo "brilbo da ausência'"26, nem ao menos retoma a fixação da instrução gratuita como dever do Estado? Os próprios preceitos enunciados nos pareceres de Rui sobre a reforma de ensino teriam sido, em 91, absolutamente desprezados. Tudo girou às voltas do ensino leigo. Houve, mais uma vez, a recorrente dissonância que tantas vezes, em outros momentos, desapontaria os brasileiros, entre a expressão jurídica e as exigências políticas da realidade social.

A geração sucessora dos sombos primeiros daquele republicanismo emergente é induzida, por inúmeros fatores, dentre os quais se destaca a eclosão da primeira Guerra Mundial, a uma onda de nacionalismo arraigado que, somado aos intentos de equacionar os problemas sociais radicalizados desde o implemento do regime republicano, volta o olhar para a sombria situação da escola pública no país. Ocorre, desde então, um novo impulsopara reavivar o antigo imaginário de estender escolas para construir um império. Com isso, as duas últimas décadas da Primeira República presenciam tanto na esfera do discurso público quanto no efetivo implemento de políticas educativas setoriais um for- 
talecimento da crença na escolarização como pilar motor da construção da nacionalidade. Acreditava-se, assim, que os desajustes mecanicamente associados àquele modelo de sociedade liberal pudessem ser erradicados por meio do caráter regenerador da instrução, redentora, por excelência, de quaisquer disfunçóes da sociedade democrática. Desiludido com os rumos pelos quais avançava a repuiblica, essemovimento articulava-se na ordem institucional, tendo por meta a correção de distorçóes de um regime considerado, em si, benéfico. Para tanto, dois instrumentos mostravam-se indispensáveis: o voto secreto, como componente indisponível da cidadania plena, e a ampliação das escolas, como dispositivos que, pelo seu próprio caráter, transformariam em cidadãos as crianças da escola primária. Ambos os procedimentosvoto secreto e instruçáo primária para todos-forneceriam a legitimidade social de que carecia a ordem pública.

Rui Barbosa bavia projetado uma escola democrática, não sendo ele mesmo um democrata na acepção mais plena da palavra. Projetou a escola democrática a partir de premissas liberais, inspiradas pelo republicanismo francês. Contudo, subsistia, nos coraçóes, nas mentes e nas vontades, todo um modelo social que continuamente resistia à mudança, ainda que fosse contida, vigiada e bastante moderada a mudança defendida... Seus discípulos retomariam, em parte, o projeto educacional do líder e do mestre Rui Barbosa e proporiam a viabilização do mesmo projeto no interior da ordem republicana, justamente como procedimento capaz de corrigir-lhe os desvios ocasionados por efeito, talvez, das resistências, das permanências, da sobrevivência do arcaísmo e do atraso nos padróes de convivência política no Brasil. Era necessário, mais do que nunca, superar o legado do "antigo regime"; impulsionar o país em direção a rumos modernos. Para isso, novamente, empunbar-se-ia a escola como promessa e como bandeira: prospecto de edificaçáo do futuro, alavanca propulsora da reconstrução nacional. Nessa ilusão partilhada, existiu uma geração de "bacharelandos" das elites políticas dos grandes centros que - na segunda metade dos anos dez-passaria a tomar por missáo os projetos educativos defendidos por Rui Barbosa. Para parafrasear expressóes consagradas porJorge Nagle na bistória 
do ensino no Brasil republicano, naquele "entusiasmo político", restaurava-se o "otimismo pedagógico" em relaçáo à escola. Política republicana e expansão da escola pareciam ser aqui emendas variadas de um mesmo soneto ${ }^{27}$.

A Primeira República constituiria, então, momento privilegiado do que Jorge Nagle denominou "entusiasmo pela educação"28: a crença na difusáo da escola como estratégia básica para incorporação das camadas subalternas da população na rota do progresso nacional. Como exemplo, citamos Sampaio Dória que, sob a manifesta inspiração de Rui Barbosa, adverte políticos e educadorespara as implicaçóes políticas dofracasso na educação:

Pergunto então: se os governantes, legisladores, ou presidentes, se desempenharem mal e pessimamente no mandato em que o povo os tiver investido, que qualificação merece o povo não só que os tolera, mas os reelege, os aplaude, thes erige estaduais? Não diremos que o povo seja cretino. Não. (...) Na primeira alternativa, está em menoridade cívica, pede tutor, nãopode governarse por si mesmo. Na segunda, pior que a menoridade, é um caso perdido de delinqüência moral coletiva. Qual destas duas pontas se crava no coração do Brasil? Estamos em menoridade cívica. (...) Dos trinta milhóes que somos, quantos sabem ler? Nem talvez, vinte por cento. E quantos, entre estes, são idôneos? Tomados como coletividade há critério seguro para a resposta. Considerai as eleições no Brasil. Com exceção da memorável campanha civilista, em que se ensaiou para não repetir, consulta direta ao povo, ao corpo eleitoral, entre nós, se limita a ratificar candidatos de camarilhas. Opovo não é ouvido sobre quem deva ser os 'seus' candidatos, os 'seus' mandatários, aqueles que, em 'seu' nome, $e$ para bem 'seu', vão exercer a 'sua' soberania. Mesmo quando dois disputam entre si, a presidência da República, o coração do povo não foi auscultado. Mandóes que se substituem à nação, usurpando-lhe a soberania, se desavieram e, como desta vez, não descera oMestre à tribuna para clamarao país a sua indiferença, faltou à tal 'banda alleman'o cimento da sua coesão precária de beterogêneos; a repulsa a Rui, isto é, a encarnação viva da consciêncianacional ${ }^{9}$.

Tomando, como vemos, explicitamente o exemplo de Rui Barbosa como a personificação viva das bandeiras democráticas. Esse pensamento, expresso no discurso da Liga Nacionalista de Sáo Paulo, desde meados da década de dez, travaria concretos esforços no sentido de oferecer ao povo sua maioridade política. 
Náobastou a institucionalizaçáo do regime republicanopara depurar o país das fraudes e da corrupçáo política. Na verdade, a lógica do pensamento diretor da conduta daquela agremiaçáo era a seguinte: bá que se oferecer ao povo condiçóes intelectuais suficientes para que ele possa escolber, no âmbito público, os representantes efetivamente mais capazes. Apreocupação com a variante democrática é tônica constante desse pensamento que teme o voto popular na ausência da instrução como seu necessário complemento. Ademocracia, sem as luzes da escolarizaçáo, "faz como criança imaginosa que constrói castelos no ar. Daí o governo de oligarquias, oligarquias reais, sem retóricas, oligarquias no sentido genuíno do termo"3o.

Sem educação, o povo permaneceria então a eterna criança a ser tutelada. Democracia em suas máos poderia vir a se tornar arma de fogo. Daío intuito claro de oferecer a sustentação pedagógica imprescindível ao escrutínio político. Abistória se encarregaria de demonstrar a dificuldade bistórica no de fato construir a modernidade brasileira, com base na democracia e na educação. Não por acaso, até boje, os governantes recordam com muita recorrência a prioridade da educação como tema do discurso. A universalização de uma escola democrática e de qualidade é ainda neste país projeto de futuro. Do passado, dialogamos com temas presentes e, pensando nisso, indagamos: será que a especificidade da educação moderna neste paús está no fato de sempre estarmos à espera dela?

\section{Notas}

*Este texto representa uma versáo atualizada do capítulo IV de minha dissertação de mestrado, que foi defendida em 1990, sob orientação do Prof. Dr. Roberto Romano, na Faculdade de Educação da Universidade de São Paulo, sobo título Rascunbos de escola na encruzilhada dos tempos, pp.173-214.

${ }^{1}$ BEISIEGEL, Celso de Rui. Estado e educação popular. São Paulo, Pioneira, 1974, p. 02.

${ }^{2}$ Acerca do tema, indico o trabalbo de CARVALHO FRANCO, Ma Silvia. "As idéias estão no lugar”. In CADERNOS DE DEBATE I: História do Brasil. São Paulo, Brasiliense (1), 1976.

${ }^{3}$ BEISIEGEL, Celso de Rui. op. cit., p. 47.

${ }^{4}$ BRESCIANI, Maria Stella Martins. Liberalismo: ideologia e controle social. São Paulo, FFLCH-USP, (mimeo). 
${ }^{5}$ Idem, vol. I, p.208.

${ }^{6}$ RUI BARBOSA. "Reforma do ensino primário e várias instituiçóes complementares da instruçấo pública." In Obras completas de Rui Barbosa, vol.X, tomo II, p. 178. Rio de Janeiro, Ministério da Educação e Saúde, 1947.

7"Depois, a educação industrial representa um dos auxiliares mais eficazes no nivelamento crescente das distinções de classes entre os bomens, não deprimindo as superioridades reais, mas destruindo as inferioridades artificiais, que alongam dessa eminências camadas laboriosas do povo, istoé, elevando a um plano cada vez mais alto a ação e o pensamento do operário." (RUI BARBOSA. "Discurso pronunciado no Lyceu de Artes e Officios em 23 de novembro de 1882”. In Orações do apóstolo. Rio de Janeiro, Edição da Revista de Língua Portuguesa, 1923, p. 103).

${ }^{8}$ Idem, p. 95.

${ }^{9}$ RUI BARBOSA. "Reforma do ensino primário e várias instituições complementares da instrução pública”. In Obras completas de Rui Barbosa. vol. X, tomo I, p.80.

${ }^{10}$ Idem, p. 96.

${ }^{11}$ RUI BARBOSA. "Reforma do ensino primário....". In Obras completas de Rui Barbosa, vol. X, tomo I, p.143.

${ }^{12}$ Idem, p. 340.

${ }^{13}$ Acerca da questão do método nos Pareceres de Rui Barbosa, existem estudos mais aprofundados. Indicaríamos a tese de doutoramento de Vera T. Valdemarin Gonçalves, intitulada O liberalismo demiurgo: estudo sobre a reforma educacional projetada nos Pareceres de Rui Barbosa, defendida em 1994 na Faculdade de Educação da USP. Outro trabalbo interessante sobre o tema éo livro de José de Arruda Penteado, intitulado A consciência didática no pensamento pedagógico de Rui Barbosa, publicado em Sáo Paulo, Pela Companhia Editora Nacional, no ano de 1984.

${ }^{14}$ Rui BARBOSA. “Reforma do ensino primário....”. In Obras completas..., vol. X, tomo II, p.33.

${ }^{15}$ Quem conbece o estado mental de nossa pátria, não terá dúvida em confessar que este é, igualmente, o achaque geral da nossa época e da nossa terra. A escola é o primeiro e o mais decisivo fator nessa deturpação da bumanidade. Como não ser assim? "Que flor solitária deu nunca de si o pensamento, o afeto, ou a vontade humana, que não estenda a sua raiz mestra até o subsolo dos primeiros anos de vida?' [Froebel]. O ponto de apoio da educaçáo deve, portanto, mudar; deixar de assentar-se exclusivamente no espírito indivídual,nasfaculdades produtoras do aluno (...) Verdades irrefragáveis que Froebel compendiou... (Idem, pp. 55-56).

16"RUI BARBOSA. "Reforma do ensino primário e várias instituições complementares da instrução pública”. In Obras completas de Rui Barbosa. vol. X, tomo II, pp. 199-202.

${ }^{17}$ Idem, p. 365.

${ }^{18}$ ROMANO, Roberto. Corpo ecristal: Marx romântico. Riode Janeiro, Guanabara, 1985, p.83.

${ }^{19}$ RUI BARBOSA. "Reforma do ensino primário....”. In Obras completas de Rui Barbosa, vol. X, tomo II, p. 371. 
20"RUI BARBOSA. 'Reforma do ensino primário e várias instituiçóes complementares da instrução pública”. In Obras completas de Rui Barbosa, vol. X, tomo II, p. 383.

${ }^{21}$ Idem, p. 26.

${ }^{22}$ ROMANO, Roberto. Lux in Tenebris; meditações sobre filosofia e cultura. São Paulo, UNICAMP/Cortez, 1987, p. 127.

${ }^{23}$ Idem, p. 124.

${ }^{24}$ NOGUEIRA, Marco Aurélio. As desventuras do liberalismo, passim. Rio de Janeiro, Paze Terra, 1984.

${ }^{25}$ RUI BARBOSA. Orações aos moços. (Os grifos são nossos). São Paulo, Edição comemorativa/Reitoria da Universidade de São Paulo, 1949, p. 24.

${ }^{26}$ A expressão é de Alfredo Bosi, que declara a propósito da Carta de 91 em matéria educacional: Obrilbo da ausência revela o distanciamento do legislador em relação ao problema da escolarização maciça do povo que cumpria ao Poder Público agenciar. (BOSI, Alfredo. "A educação e a cultura nas constituições brasileiras." In Novos Estudos Cebrap, no 14, fev., 1986, p. 63).

${ }^{27}$ A esse respeito, recomendamos a tese de doutoramento defendida por Rosa Fátima de Souza, em 1996 na FEUSP, sob o título: Templos de civilização: um estudo sobre a implantação dos Grupos Escolares no Estado de São Paulo (1890-1910).

${ }^{28}$ Jorge Nagle, tanto em seu livro Educação e sociedade na Primeira RepúblicaSão Paulo, EPU/MEC, 1976-quanto no capítulo que escreve para o livro História geral da civilização brasileira. São Paulo, Difel, 1983, tomo III, volume II, $2^{a}$ ed. - intitulado "A educação na Primeira República", fornece um panorama riquíssimo das repercussóes pedagógicas provenientes do fervor ideológico berdado pela tradição republicana. Os trabalbos de Nagle representam incontestavelmente uma referência imprescindível a todos os que se embrenbam pelo estudo da bistória da educação brasileira no período republicano.

${ }^{29}$ DORIA, Sampaio. “O governo do povo”. In Partido Democrático, O voto secreto. São Paulo, Livraria Liberdade, 1927, pp. 276-277. Este texto procede de conferência pronunciada em julbo de 1922, na cidade de Campinas, com o nome de "Liga Nacionalista".

${ }^{30}$ Idem, p. 280. 
282 